\title{
Characterization of the Temperature Conditions of Inside Narrow Rocky Outcrops that Serve as a Habitat for Semi-Fossorial Mammals
}

\author{
Masahiro A. Iwasa*, Mayuh Tabata \\ Course in Natural Environment Studies, Graduate School of Bioresource Sciences, Nihon University, Fujisawa, Japan \\ Email: ${ }^{*}$ iwasa.masahiro@nihon-u.ac.jp
}

How to cite this paper: Iwasa, M.A. and Tabata, M. (2016) Characterization of the Temperature Conditions of Inside Narrow Rocky Outcrops that Serve as a Habitat for Semi-Fossorial Mammals. Open Journal or Animal Sciences, 6, 247-258.

http://dx.doi.org/10.4236/ojas.2016.64030

Received: July 14, 2016

Accepted: August 14, 2016

Published: August 17, 2016

Copyright $\odot 2016$ by authors and Scientific Research Publishing Inc. This work is licensed under the Creative Commons Attribution International License (CC BY 4.0).

http://creativecommons.org/licenses/by/4.0/ (c) (i) Open Access

\begin{abstract}
We characterized the temperature conditions inside narrow rocky outcrops that served as habitats for semi-fossorial small mammals in a mountainous locality on the Japanese Islands. Usually, it is considered that the narrow rocky outcrops have poorer resources than the soil ground of forest floors, which have rich vegetation and nutrition. On the basis of this tendency, it is considered that ecologically dominant species occupy the rich soil habitats and subordinate species are chased away to the narrow rocky outcrops by ecological species competitions, resulting in habitat segregation. However, the present temperature data revealed that the temperatures inside rocky terrains were more stable than the shaded ambient temperatures in the forest. The rocky habitats were apparently colder in summer and warmer in winter, in both daily maximum and minimum temperatures, than the ambient temperatures in the forest during the research period. In addition, the daily difference between maximum and minimum temperatures in the rocky habitats was apparently smaller than that of the ambient ones. These temperature conditions in the narrow rocky outcrops are advantageous to the small mammalian metabolic system. Namely, we estimate that the semi-fossorial small mammals are not chased out by the dominant species through ecological competitions and that the semi-fossorial small mammals may occupy the narrow rocky outcrops as a more advantageous habitat than the forest floor.
\end{abstract}

\section{Keywords}

Temperature, Narrow Rocky Outcrops, Habitat, Semi-Fossorial Mammals

\section{Introduction}

In natural conditions of Honshu of the Japanese Islands, the red-toothed shrews, Sorex 
shinto and S. hosonoi, the Japanese shrew-moles, Dymecodon pilirostris and Urotrichus talpoides, the red-backed voles, Eothenomys andersoni and E. smithii, and the Japanese field mice, Apodemus argenteus and A. speciosus, are recognized in rock outcrops as small mammalian species [1]-[4]. Of them, the Sorex shrews, D. pilirostris, $U$. talpoides, E. andersoni and E. smithii use incomplete burrows and rock crevices as well as ground, and are considered to be typically semi-fossorial species [1]-[4]. On the other hand, the Apodemus species also widely occur on forest floors, grass fields, and cultivated fields as terrestrial species, and particularly $A$. argenteus shows spatial usage of trees as a semi-arboreal species [4]-[7].

Generally, rocky outcrops (Figure 1(a)) have poorer vegetable diversity and resources and soil nutrients than the rich soil grounds of forest floors, which bear rich
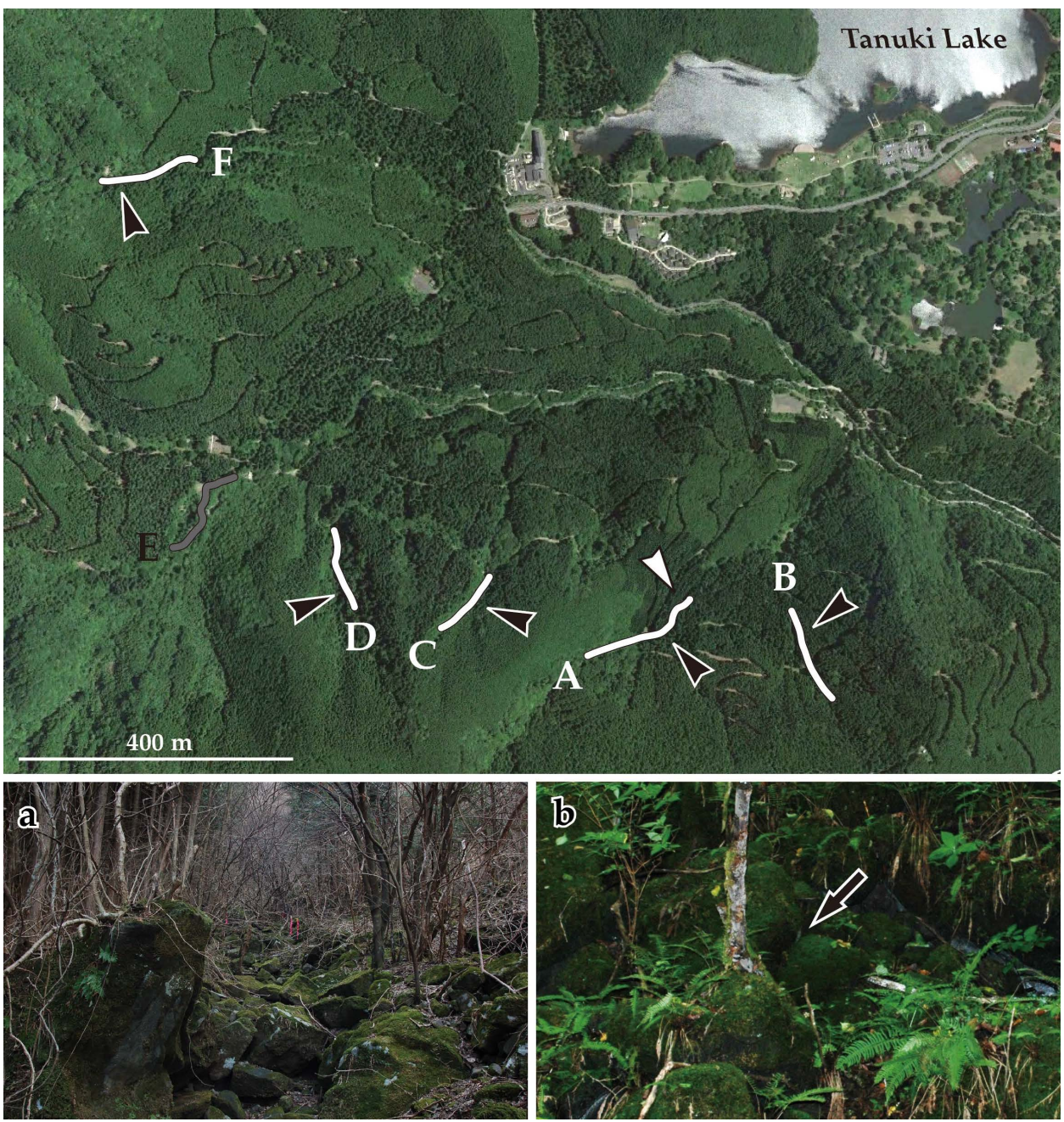

Figure 1. Current research sites (A, B, C, D and F, above) that are identical to those in previous study [3]. Black lines indicate rocky terrain valleys. White arrowhead and black arrowheads indicate the present logger set points: the control and the inside crevices of rocky terrains, respectively. Photographs indicate a typical appearance of data logger setting sites of a rocky terrain ((a), site F) in early spring and of those typical inside a crevice indicated by an arrow (b). The data logger is set at $30 \mathrm{~cm}$ inside a crevice from the rocky outcrops. 
vegetation as useful resources for small animals [8]-[12]. Considering these situations and micro-habitats of the small mammals, small mammals inhabiting areas with poor vegetable resource and soil conditions, such as the rocky outcrops, are considered to be ecologically subordinate species from the standpoint of interspecific competitions and interspecific interactions [13]-[20]. For example, it is known that D. pilirostris seems to be chased away from the rich soil areas to the rocky outcrops by a more dominant species, $U$. talpoides, as an example of interspecific ecological competitions [13]-[21]. In addition, the red-backed voles, $E$. andersoni and E. smithii, are frequently recognized in rocky outcrops, and it is estimated that they also competed with the Japanese field mice, A. speciosus and $A$. argenteus, in the natural environments because both Apodemus mice are dominant in entire areas of their habitats [2]-[4] [22]. According to the ecological competition among these small mammals only, however, it is difficult to explain why $D$. pilirostris, E. andersoni and E. smithii are constantly recognized at screes and rocky outcrops as rock-dwelling species, particularly in situations where there is an absence of the dominant species, such as in alpine and subalpine areas [14] [23]. Considering this fact, it is thought that they prefer the rocky outcrops as habitats irrespective of the interspecific competition causing habitat segregation [18] [24].

Here, we hypothesized the presence of an advantage in the narrow rocky outcrop habitats over the forest floor habitats that have rich soil and vegetation. In this study, of the several environmental elements for the habitat preferences of the terrestrial and semi-fossorial mammals, we focused on the temperature of the habitat and evaluated the temperature conditions in narrow rocky outcrops as an ecological habitat advantage for these species.

\section{Materials and Methods}

\subsection{Research Sites}

We set five sites, A-F except for site E, showing narrow rocky outcrops with slight daylight in natural broadleaf forests and plantations of the Japanese cedar Cryptomeria japonica in Fujinomiya, Shizuoka Pref., Honshu, Japan $\left(35^{\circ} 20^{\prime} \mathrm{N}, 138^{\circ} 32^{\prime} \mathrm{E}\right.$, alt. 650 - 750 $\mathrm{m}$; Figure 1), as in our previous research [3].

\subsection{Research Fauna in the Sites}

We researched terrestrial and semi-fossorial small mammal fauna at these sites using Sherman traps in 2004-2009, and the number of traps were as follows: site A (control), 120 trap-nights; site A, 240 trap-nights; site B, 360 trap-nights; site C, 170 trap-nights; site $\mathrm{D}, 480$ trap-nights; site F, 580 trap-nights.

\subsection{Collection of Temperature Data}

To record temperature data for the rocky condition, we put five temperature data loggers (HOBO Water-Temp Pro H20) into the crevices of rocks at $30 \mathrm{~cm}$ inside from the rock surface at each site (Figure 1). The temperature was recorded at 15-min intervals from March 16, 2007, to March 15, 2008 (35,040 temperature logs in total). As a control 
to record shaded ambient temperature, one logger was set at breast height of a wood 20 $\mathrm{m}$ inside from the forest edge in the Japanese cedar plantation at site A (Figure 1). Unfortunately, serious landslides occurred at site $\mathrm{C}$ due to heavy rains, and that data logger was crushed in 2007. We used data previously obtained as preliminary research from September 26, 2005 to August 19, 2006 (326 days, with a total of 31,296 temperature logs) for the present analysis. Therefore, we did not use the data of site $\mathrm{C}$ for current statistical analysis. We took long time to analyze the current temperature data and it was delayed to release them to date.

To obtain time differences as time lags between the control and each site for daily maximum $\left(D T_{\max }\right)$ and minimum $\left(D T_{\min }\right)$ temperatures, we used the following formula: time lag $\left(T_{\text {lag }}\right)=$ |time recorded at control - time recorded at each site $\mid$.

\section{Results}

\subsection{Small Mammalian Fauna in the Sites}

The trapping results are shown in Figure 2. From all of the sites showing rocky outcrops, with the exception of site A (control), several species of small mammals were obtained. In addition, $A$. speciosus, $A$. argenteus, and $U$. talpoides were collected from forest floors in site A (control). In all of the sites, including site A (control), rock-dwelling species, such as $D$. pilirostris and E. smithii, were confirmed only in the narrow rocky outcrops (Figure 2).

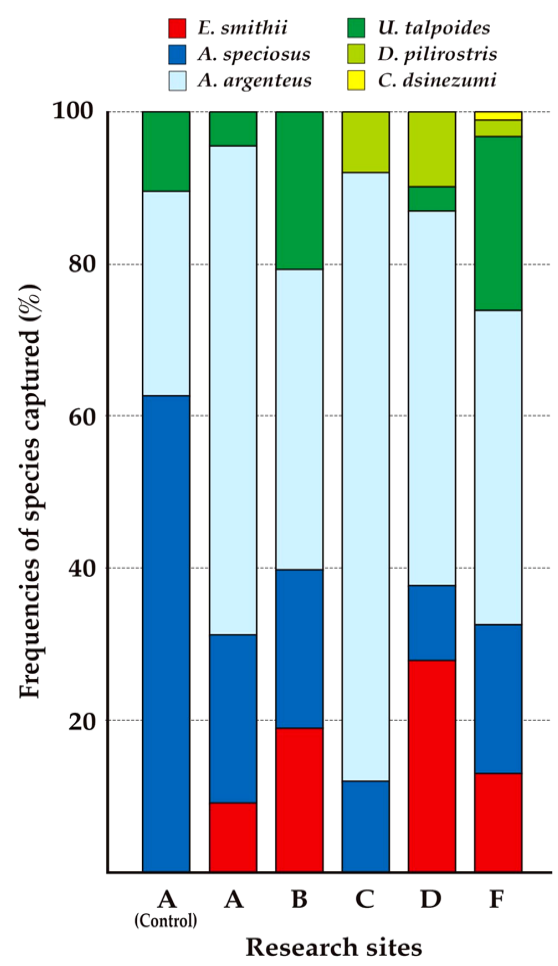

Figure 2. Frequencies of small mammals captured at the control and the rocky terrain sites. 


\subsection{Temperature Data}

The temperatures inside the rocky outcrops at the four sites and in the control were recorded as shown in Figure 3. The maximum temperature throughout all of the days ranged from $20.39^{\circ} \mathrm{C}$ to $23.02^{\circ} \mathrm{C}$ at the four sites but was $29.69^{\circ} \mathrm{C}$ at the control in summer (Table 1 and Figure 3). On the other hand, the minimum temperature throughout all of the days ranged from $-3.18^{\circ} \mathrm{C}$ to $-0.31^{\circ} \mathrm{C}$, and that of the control was $-6.52^{\circ} \mathrm{C}$ in winter (Table 1 and Figure 3). In addition, the $D T_{\max }$ at the four rocky sites $(\mathrm{A}, \mathrm{B}, \mathrm{D}$, and $\mathrm{F})$ differed significantly from that at the control by Dunnett test at $p=$ 0.001 (Table 1). On the other hand, the $D T_{\min }$ at the four rocky sites $(\mathrm{A}, \mathrm{B}, \mathrm{D}$, and $\mathrm{F}$ ) did not differ from that at the control at $p=0.05$ (Table 1). Moreover, the average of the difference $\left( \pm S D\right.$ ) between the $D T_{\max }$ and $D T_{\min }$ at the five rocky sites ranged from $0.58 \pm 0.481$ to $1.10 \pm 0.581$ and differed significantly from that at the control, $5.31 \pm$ 2.093 (Table 1).

The times recorded with the $D T_{\max }$ and $D T_{\min }$ were partially delayed from those of the control throughout the annual period. The data logger of the control mostly recorded the times of the $D T_{\max }$ and $D T_{\min }$ at during the daytime (10:00-16:00) and early morning (2:00-8:00), respectively (Figure 4). Here, we divided the $T_{\text {lag }}$ into four periods, $|0| \pm 3$ hours, $|6| \pm 3$ hours, $|12| \pm 3$ hours, and $|18| \pm 3$ hours, in all of the sites except for site C. According to the $T_{\text {lag }}$ between the times recorded in the control and in each site for the $D T_{\max }$ and $D T_{\min }, 100-216$ days $(27.4 \%-59.2 \%)$ at $|0| \pm 3$ hours and 56 - 113 days $(15.3 \%-31.0 \%)$ at $|12| \pm 3$ hours were recorded in comparison with the

Table 1. Temperature data in the control and five sites.

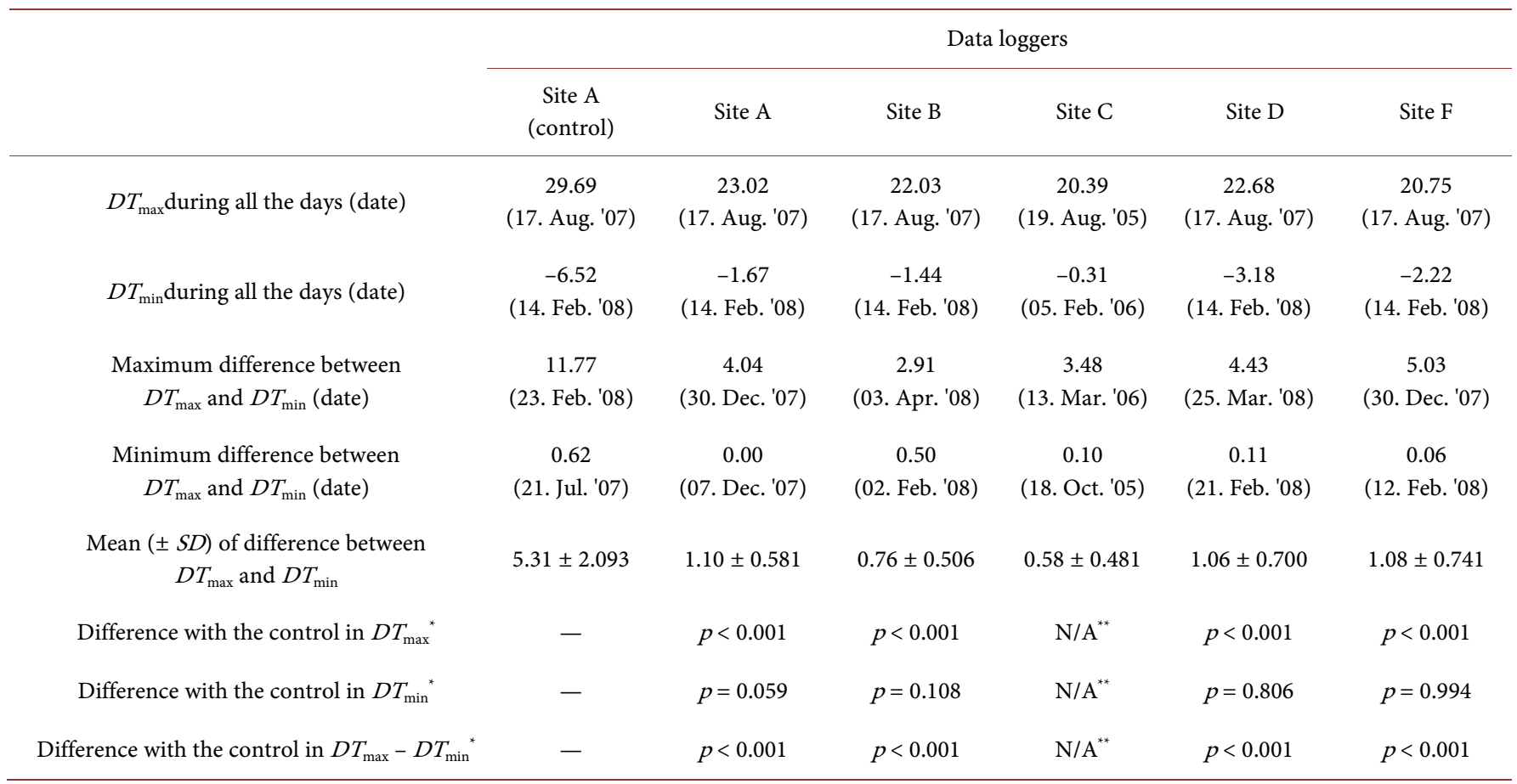

"Multipe comparisons by Dunnett test. "N/A, not applicable; site C data were obtained during 2005-2006 and we did not compare with the control data obtained during 2007-2008. 

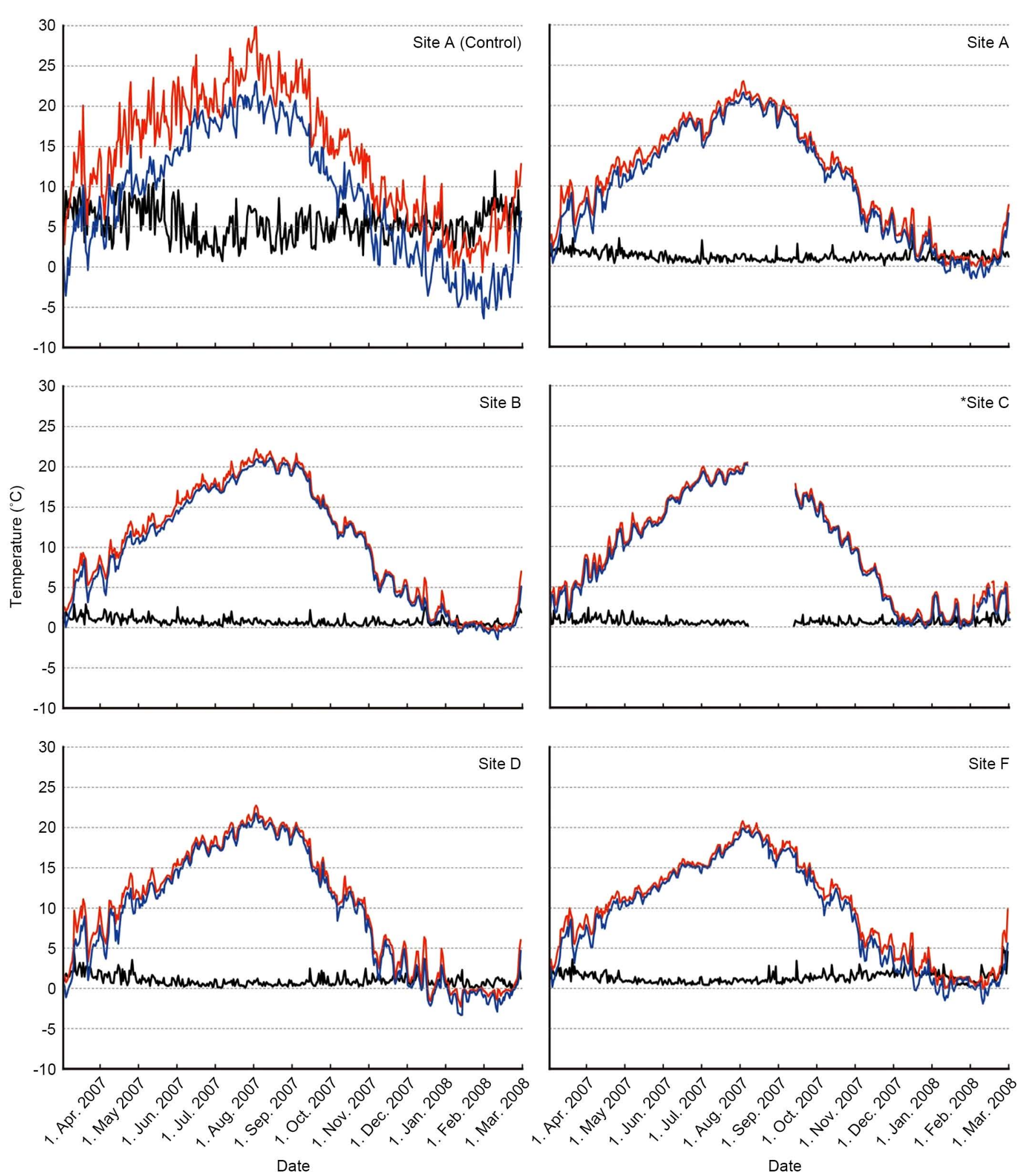

Figure 3. Daily maximum ( $D T_{\max }$ : red-colored lines) and minimum ( $D T_{\min }$ : blue-colored lines) temperatures during the current research period. Black lines indicate the differences between $D T_{\max }$ and $D T_{\min }$. The data at site $\mathrm{C}$ (asterisk) were obtained from another period (September 26, 2005-August 19, 2006, 326 days) and the dating was regulated by the other site data: March 16, 2006-August 19, 2006, and September 25, 2005-December 31, 2005/January 1, 2006-March 15, 2006. 

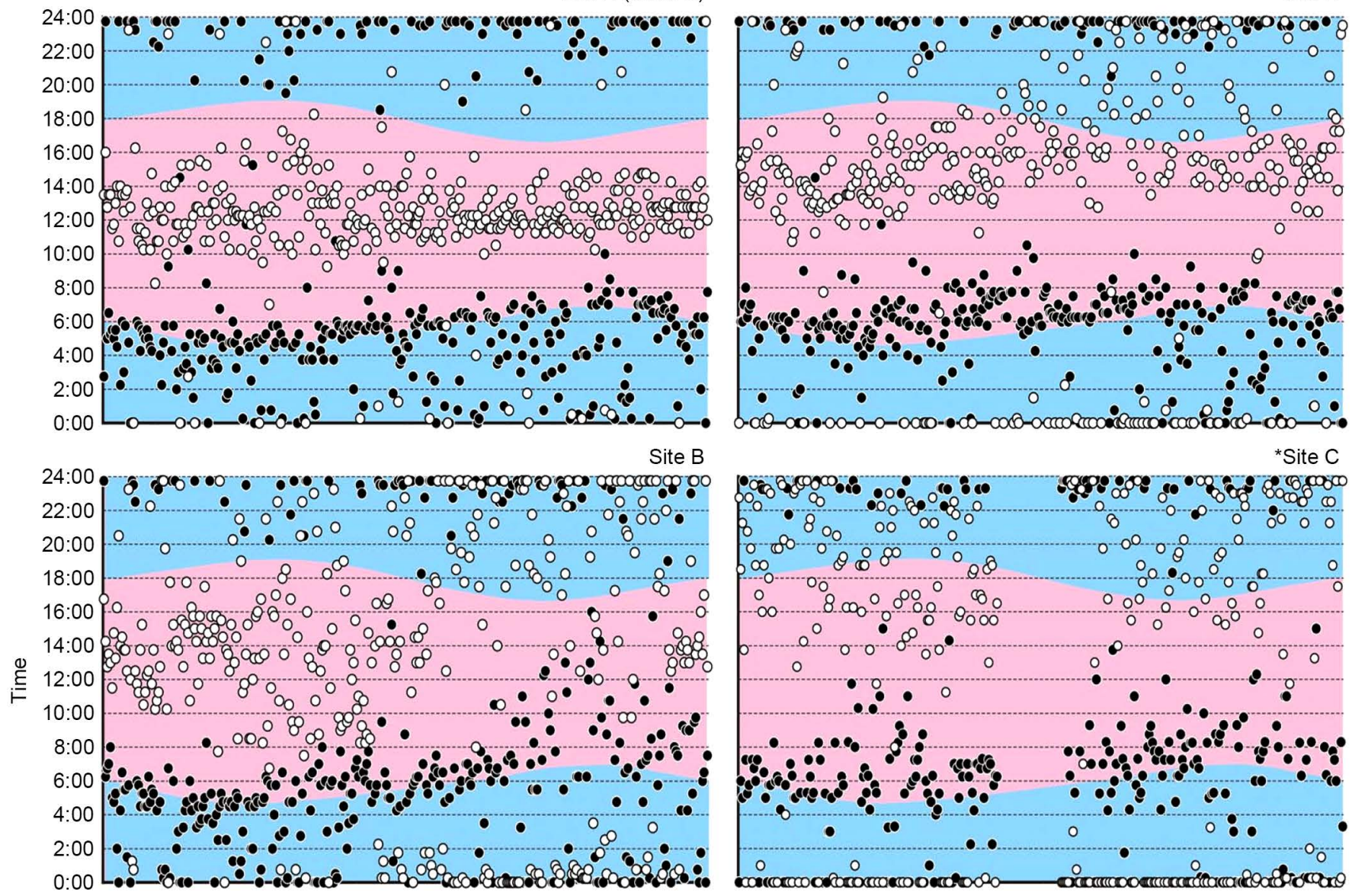

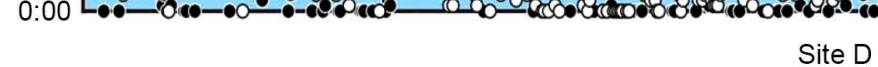

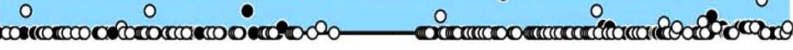
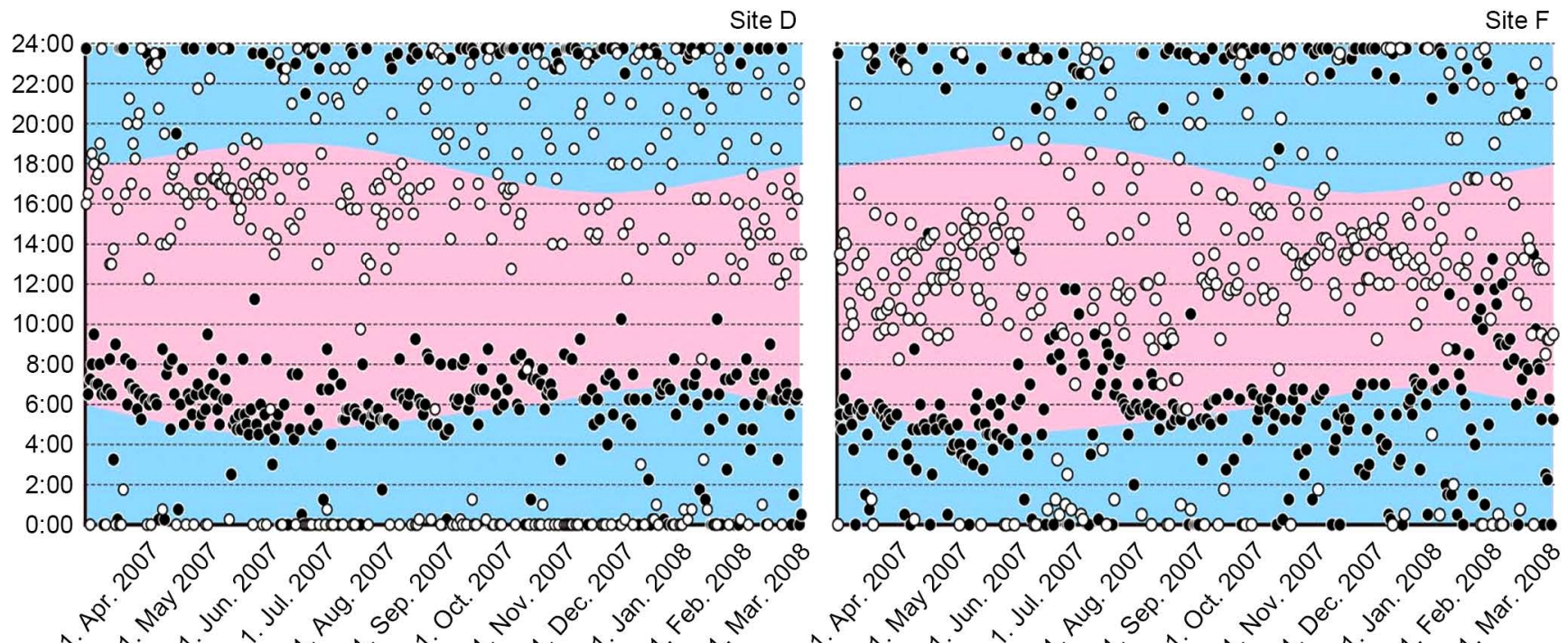

Date

Date

Figure 4. Times of the recorded daily maximum ( $D T_{\max }$ : white circles) and minimum $\left(D T_{\min }\right.$ : black circles) temperatures during current research period. Blue-colored and pink-colored areas indicate night times (from sunset to sunrise) and day times (from sunrise to sunset), respectively. The data at site C (asterisk) were obtained from another period (September 26, 2005-August 19, 2006,326 days), and the dating was regulated by the other site data: March 16, 2006-August 19, 2006, and September 25, 2005-December 31, 2005/January 1, 2006March 15, 2006. 
control time for the $D T_{\max }$ (Table 2 and Figure 5). In contrast, 242 - 277 days (66.3\% $75.9 \%)$ at $|0| \pm 3$ hours and $5-18$ days $(1.4 \%-4.9 \%)$ at $|12| \pm 3$ hours were recorded in comparison with the control time for the $D T_{\min }$ (Table 2 and Figure 5).

\section{Discussion}

In the present trapping results, a few species of terrestrial and semi-fossorial small mammals were collected at the rocky outcrops irrespective of capturing only three species of terrestrial small mammals at forest floors in site A (control) (Figure 2). Thus, the current capturing results suggest that the rocky outcrops are appropriate as habitats for terrestrial and semi-fossorial small mammals. Actually, D. pilirostris and E. smithii are considered to be rock-dwelling species according to ecological research [3] [21].

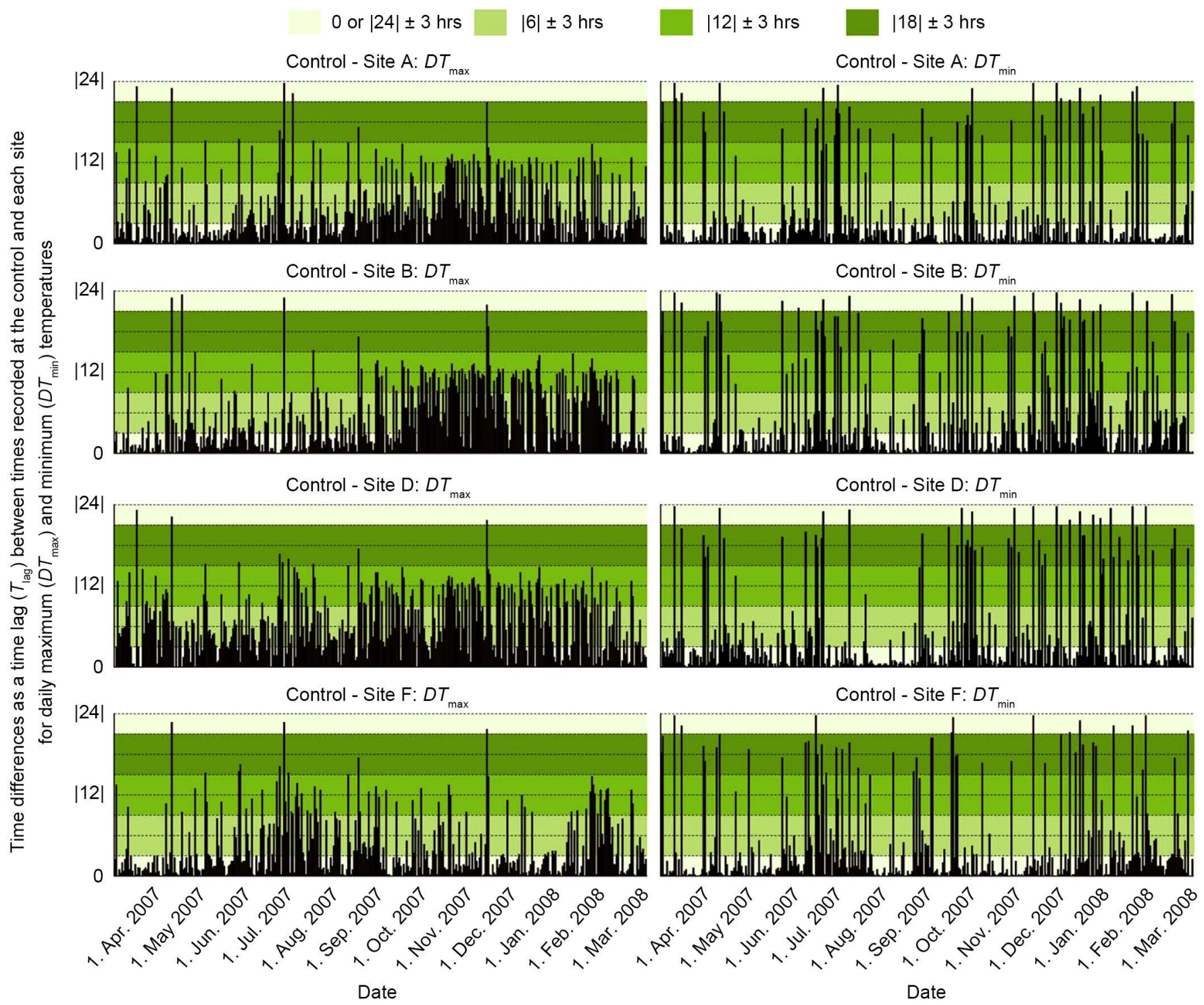

Figure 5. Time differences as a time lag $\left(T_{\text {lag }}\right)$ between the times recorded at the control and each site for the daily maximum $\left(D T_{\max }\right)$ and minimum $\left(D T_{\min }\right)$ temperatures. 
Table 2. Number of days (frequency) in each time difference as a time lag $\left(T_{\text {lag }}\right)$ between the times recorded at the control and each site for the daily maximum $\left(D T_{\max }\right)$ and minimum $\left(D T_{\min }\right)$ temperatures.

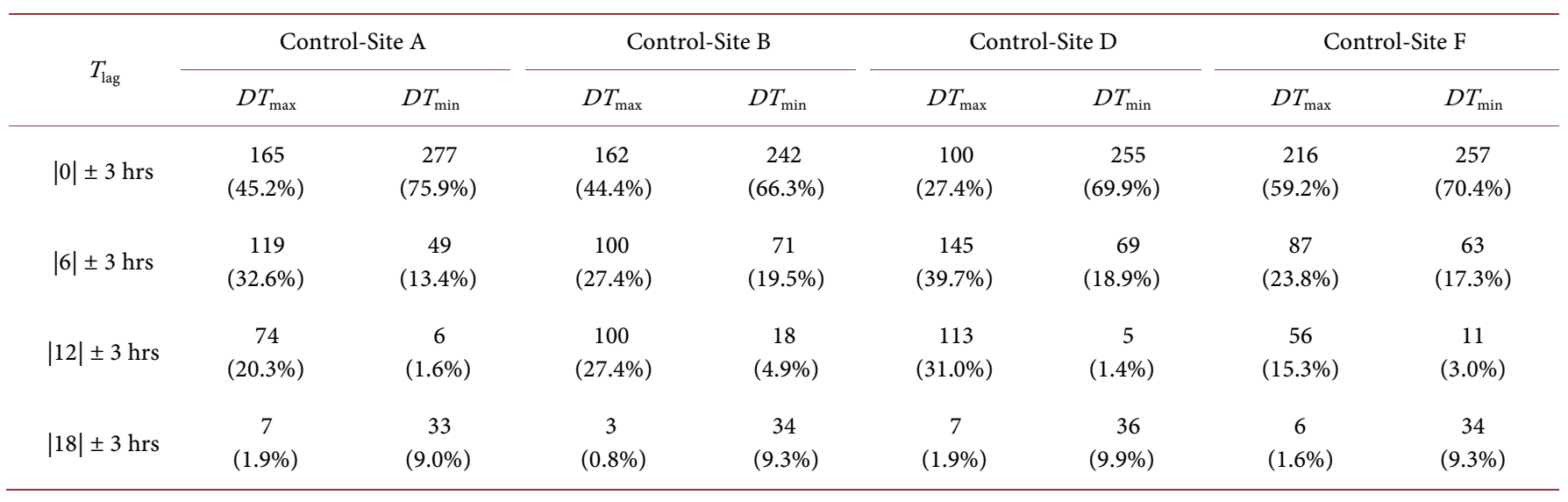

On the basis of the present data from the loggers, the five rocky outcrop sites fundamentally showed specified temperature conditions in comparison with the shaded ambient temperature at the control of site A (Table 1 and Figure 3 ). The present data revealed that the $D T_{\max }$ inside the cracks of the rocky outcrops was apparently lower in summer and higher in winter than the shaded ambient temperature at the control during the research period (Table 1). Actually, the data logger recorded approximately $20^{\circ} \mathrm{C}$ as the maximum temperature in summer and $0{ }^{\circ} \mathrm{C}$ as minimum temperature in winter (Table 1 and Figure 3). Such a tendency of temperature differences between above ground and underground was also observed in a habitat of the red-backed vole in mountainous areas [25]. Generally, ectothermal animals are sensitive to cold stress and endothermal animals to heat stress [26]. For example, degus distributed in mountainous areas of Chile have daily activities in the morning and at night in summer and in the daytime in winter, and such activities are observed at approximately $20^{\circ} \mathrm{C}$ in summer and $10^{\circ} \mathrm{C}$ in winter [27]. In addition, it has been reported that metabolic rates are higher in summer than in winter in red-backed vole species [25] [28]. Moreover, for ground squirrels, the percentage of time spent in burrows and shady areas increases with a rise in ambient temperature, leading them to desire cooler conditions [29]. Considering the current colder temperatures inside rocky outcrops in summer and the seriousness of heat stress for mammals [30], it is understandable that the small mammals that are adaptive to the temperate climate prefer the present rocky condition, which is colder than the ambient condition, particularly in summer, as shown in the pikas preferring rocky outcrops [31]. Thus, the present lower $D T_{\max }$ in the rocky outcrops, particularly in summer, is a physiologically advantageous condition for small mammals.

In terms of daily temperature fluctuation, the daily temperature of rocky terrains is stable within approximately $1^{\circ} \mathrm{C}$ (Table 1 ). Such a tendency of a smaller daily temperature fluctuation was also observed in an underground habitat of the red-backed vole in mountainous areas [25]. On the basis of the study about the relationship between body size and temperature regulation, small mammals with a larger body surface as compared to their body mass have lower adaptation potential to a wide range of air temper- 
atures than large mammals with a smaller body surface as compared to their body mass [32]. If small mammals live under the habitat environments and the ambient temperature is suitable to large mammals, small mammals have to increase their metabolic rate [33]. In addition, according to a previous study [34], lower lethal hypothermia temperature and higher lethal hyperthermia temperature are present at variable ambient temperatures in mammals. Moreover, in such a temperature range, there is a thermal neutral zone in which the metabolic rate is minimal and the animal is at its basal metabolic rate. Generally, considering the thermal neutral zone, daily and annually lower fluctuations of ambient temperature are desirable to endothermal animals, particularly small mammals. Accordingly, we can expect that the lower daily difference between the $D T_{\max }$ and $D T_{\min }$ as a lower fluctuation of temperature is suitable for small mammalian metabolic systems. Thus, it is estimated that the present daily stable temperature conditions in the rocky outcrops are advantageous for the endothermal regulation mechanism in the metabolic system of small mammals.

The times of the $D T_{\max }$ and $D T_{\min }$ were recorded with a delay from those of the control. In particular, in the four rocky terrains at sites A, B, D, and F, $143-268$ days $(39.1 \%-70.7 \%)$ were delayed by $|6-12| \pm 3$ hours from the ambience in the control (Table 2). Namely, the present results indicate that the heat potential of rocks is apparently different from that of the ambient air, and the warming on most days tends to be delayed a half day from that of the ambient air, particularly from autumn through spring (Figure 5). As a similar example, seasonal changes in activity times are known to depend on the habitat temperatures in nocturnal degus in order to control the most appropriate body temperature [27] [35]. Thus, it is thought that the time delay of the $D T_{\max }$ at the rocky outcrops seems to be more advantageous than the forest floors for the nocturnal activities of semi-fossorial small mammals, particularly in cold seasons.

\section{Acknowledgements}

This study was supported in part by Grants-in-Aid for Scientific Research (No. 17770074) from the Ministry of Education, Science, Sports, and Culture, Japan.

\section{References}

[1] Imaizumi, Y. (1960) Colored Illustrations of the Mammals of Japan. Hoikusha, Osaka. (In Japanese)

[2] Iwasa, M.A. (2008) Chapter 2: Speciation in Relic Populations-Red-Backed Voles. In: Motokawa, M., Ed., Mammalogy in Japan, Vol. 1, University of Tokyo Press, Tokyo, 59-83. (In Japanese)

[3] Tabata, M. and Iwasa, M.A. (2013) Environmental Factors for the Occurrence of the Smith's Red-Backed Vole, Eothenomys smithii, in Rocky Terrains at the Foot of Mt. Fuji in Central Japan. Mammal Study, 38, 243-250. http://dx.doi.org/10.3106/041.038.0408

[4] Ohdachi, S.D., Ishibashi, Y., Iwasa, M.A., Fukui, D. and Saitoh, T. (2015) The Wild Mammals of Japan. 2nd Edition, Shoukadoh, Kyoto.

[5] Sekijima, T. (1997) Evaluation of Vertical Habitat Use in Apodemus argenteus and A. speciosus, by the Footprint Recording Method. Japanese Journal of Ecology, 47, 151-158 (in 
Japanese with English Abstract).

[6] Sekijima, T. (1999) Seasonal Changes in Microhabitat Uses in Apodemus argenteus and $A$. speciosus. Mammalian Science, 39, 229-237. (In Japanese with English Abstract)

[7] Sekijima, T. (2004) Does Interspecific Competition Affect the Vertical Habitat Segregation of Apodemus argenteus and Apodemus speciosus? Experimental Evaluation by Removal and Food Supplementation. Mammal Study, 29, 97-104.

http://dx.doi.org/10.3106/mammalstudy.29.97

[8] Wiser, S.K., Peet, R.K. and White, P.S. (1996) High-Elevation Rock Outcrop Vegetation of the Southern Appalachian Mountains. Journal of Vegetation Science, 7, 703-722.

http://dx.doi.org/10.2307/3236382

[9] Ermakov, N., Chytry, M. and Valachovic, M. (2006) Vegetation of the Rock Outcrops and Screes in the Forest-Steppe and Steppe Belts of the Altai and Western Sayan Mts., Southern Siberia. Phytocoenologia, 36, 509-545.

http://dx.doi.org/10.1127/0340-269X/2006/0036-0509

[10] Miura, Y. and Okitsu, S. (2006) Seed Transporting Routes and Hoarding Behaviors of Wood Mice for Quercus mongolica var. grosseserrata Acorns and the Distribution of the Seedlings in the Boundary between a Block Field and Sasa Shrubs. Japanese Journal of Forest Environment, 48, 25-31. (In Japanese with English Abstract)

[11] Ikeda, F. and Kikuchi, T. (2007) Environmental Factors Controlling Vegetation Pattern on Block Slope around Sensui Pass, the South Japan Alps. Japanese Journal of Forest Environment, 49, 1-7. (In Japanese with English Abstract)

[12] Carmo, F.F. and Jacobi, C.M. (2016) Diversity and Plant Trait-Soil Relationships among Rock Outcrops in the Brazilian Atlantic Rainforest. Plant and Soil, 403, 7-20. http://dx.doi.org/10.1007/s11104-015-2735-7

[13] Tokuda, M. (1953) Small Mammals from Hakkoda (Aomori Prefecture) with Special Reference to "Allopatric" Shrew-Moles in This District and Other Districts of Japan. Ecological Review, 13, 129-134.

[14] Imaizumi, Y., Yoshiyuki, M., Obara, I., Tsuchiya, K. and Imaizumi, T. (1969) Mammal Communities and "Competition by Power" as a Factor of Segregated Distribution of Urotrichus and Dymecodon. Journal of the Mammalogical Society of Japan, 4, 63-73 (in Japanese with English Résumé).

[15] Galindo, C. and Krebs, C.J. (1985) Habitat Use and Abundance of Deer Mice: Interactions with Meadow Voles and Red-backed Voles. Canadian Journal of Zoology, 63, 1870-1879. http://dx.doi.org/10.1139/z85-278

[16] Dickman, C.R. (1991) Mechanisms of Competition among Insectivorous Mammals. Oecologia, 85, 464-471. http://dx.doi.org/10.1007/BF00323757

[17] Canova, L. (1993) Resource Partitioning between the Bank Vole Clethrionomys glareolus and the Wood Mouse Apodemus sylvaticus in Woodland Habitats. Bollettino di Zoologia, 60, 193-198. http://dx.doi.org/10.1080/11250009309355809

[18] Borghi, C.E., Giannoni, S.M. and Martinez-Rica, J.P. (1994) Habitat Segregation of Three Sympatric Fossorial Rodents in the Spanish Pyrenees. Zeitschrift für Säugetierkunde, 59, 5257.

[19] Schmidt, K.A., Manson, R. and Lewis, D. (2005) Voles Competing with Mice: Differentiating Exploitative Interference and Apparent Competition Using Patch Use Theory. Evolutionary Ecology Research, 7, 273-286.

[20] Hille, S.M. and Mortelliti, A. (2010) Microhabitat Partitioning of Apodemus flavicollis and Myodes glareolus in the Sub-Montane Alps: A Preliminary Assessment. Hystrix, the Italian 
Journal of Mammalogy, 21, 157-163.

[21] Imaizumi, Y. and Imaizumi, T. (1972) Habitat Segregation between Two Species of Japanese Shrew-Moles. Zoological Magazine, 81, 49-55. (In Japanese with English Abstract)

[22] Iwasa, M.A. (2000) Variation of Skull Characteristics in the Anderson's Red-Backed Vole, Eothenomys andersoni, from Nagano City, Central Honshu, Japan. Mammal Study, 25, 125-139. http://dx.doi.org/10.3106/mammalstudy.25.125

[23] Miyao, T., Morozumi, T., Morozumi, M., Hanamura, H., Akahane, H. and Sakai, A. (1963) Small Mammals on Mt. Yatsugatake. I. Small Mammals in the Subalpine Forest Zone on Mt. Yatsugatake. Zoological Magazine, 72, 133-138. (In Japanese with English Summary)

[24] Torre, I. and Arrizabalaga, A. (2008) Habitat Preferences of the Bank Vole Myodes glareolus in a Mediterranean Mountain Range. Acta Theriologica, 53, 241-250.

http://dx.doi.org/10.1007/BF03193120

[25] Merritt, J.F. (1984) Growth Patterns and Seasonal Thermogenesis of Clethrionomys gapperi Inhabiting the Appalachian and Rocky Mountains of North America. In: Merritt, J.F., Ed., Winter Ecology of Small Mammals, Carnegie Museum of Natural History, Pittsburgh, 201224.

[26] Pörtner, H.O. (2002) Climate Variations and the Physiological Basis of Temperature Dependent Biogeography: Systematic to Molecular Hierarchy of Thermal Tolerance in Animals. Comparative Biochemistry and Physiology Part A: Molecular \& Integrative Physiology, 132, 739-761. http://dx.doi.org/10.1016/S1095-6433(02)00045-4

[27] Kenagy, G.J., Nespolo, R.F., Vásquez, R.A. and Bozinovic, F. (2002) Daily and Seasonal Limits of Time and Temperature to Activity of Degus. Revista Chilena de Historia Natural, 75, 567-581. http://dx.doi.org/10.4067/S0716-078X2002000300008

[28] Rosenmann, M., Morrison, P. and Feist, D. (1975) Seasonal Changes in the Metabolic Capacity of Red-Backed Voles. Physiological and Biochemical Zoology, 48, 303-310. http://dx.doi.org/10.1086/physzool.48.3.30160953

[29] Sharpe, P.B. and van Home, B. (1999) Relationships between the Thermal Environment and Activity of Piute Ground Squirrels (Spermophilus mollis). Journal of Thermal Biology, 24, 265-278. http://dx.doi.org/10.1016/S0306-4565(99)00021-2

[30] Leon, L.R., Gordon, C.J., Helwig, B.G., Rufolo, D.M. and Blaha, M.D. (2010) Thermoregulatory, Behavioral, and Metabolic Responses to Heatstroke in a Conscious Mouse Model. American Journal of Physiology-Regulatory, Integrative and Comparative Physiology, 299, R241-R248. http://dx.doi.org/10.1152/ajpregu.00309.2009

[31] Ieiri, A. and Yanagawa, H. (2009) Habitat of Northern Pikas (Ochotona hyperborea yesoensis) in the Low Altitude Area at the Southern Tip of the Hidaka Mountains. Research Bulletin of Obihiro University, 30, 53-60. (In Japanese with English Abstract)

[32] Phillips, P.K. and Heath, J.E. (1995) Dependency of Surface Temperature Regulation on Body Size in Terrestrial Mammals. Journal of Thermal Biology, 20, 281-289. http://dx.doi.org/10.1016/0306-4565(94)00061-M

[33] Brown J.H., Gillooly, J.F., Allen, A.P., Savage, V.M. and West, G. (2004) Toward a Metabolic Theory of Ecology. Ecology, 85, 1771-1789. http://dx.doi.org/10.1890/03-9000

[34] Eckert, R. and Randall, D.J. (1988) Animal Physiology: Mechanisms and Adaptations. 3rd Edition, W. H. Freeman \& Co. Ltd., San Francisco.

[35] Kenagy, G.J., Vásquez, R.A., Barnes, B.M. and Bozinovic, F. (2004) Microstructure of Summer Activity Bouts of Degus in A Thermally Heterogeneous Habitat. Journal of Mammalo$g y$, 85, 260-267. http://dx.doi.org/10.1644/1545-1542(2004)085<0260:MOSABO>2.0.CO;2 
Submit or recommend next manuscript to SCIRP and we will provide best service for you:

Accepting pre-submission inquiries through Email, Facebook, LinkedIn, Twitter, etc. A wide selection of journals (inclusive of 9 subjects, more than 200 journals)

Providing 24-hour high-quality service

User-friendly online submission system

Fair and swift peer-review system

Efficient typesetting and proofreading procedure

Display of the result of downloads and visits, as well as the number of cited articles

Maximum dissemination of your research work

Submit your manuscript at: http://papersubmission.scirp.org/ 